\title{
Meningkatkan keterampilan metakognisi dan berpikir kritis siswa melalui pembelajaran model pemecahan masalah dengan strategi konflik-kognitif
}

\author{
${ }^{1}$ Roniati Sukaisih, ${ }^{2 \star}$ M. Muhali, ${ }^{3}$ Muhammad Asy'ari \\ ${ }^{1}$ Madrasah Aliyah Negeri 3 Lombok Tengah. \\ 2Program Studi Pendidikan Kimia, FSTT, Universitas Pendidikan Mandalika \\ ${ }^{3}$ Program Studi Pendidikan Olahraga dan Kesehatan, FIKKM, Universitas Pendidikan Mandalika
}

*Correspondence e-mail: muhali@ikipmataram.ac.id

\begin{abstract}
Abstrak: Pembelajaran saat ini menekankan siswa untuk mampu belajar dengan menerapkan keterampilanketerampilan berpikir abad 21 sesuai tuntutan kurikulum 2013 maupun edisi revisi seperti berpikir kritis dan metakognisi. Penelitian ini bertujuan untuk meningkatkan keterampilan metakognisi dan keterampilan berpikir kritis siswa dalam pembelajaran fisika melalui implementasi model pemecahan masalah dengan strategi konflik kognitif. Penelitian ini merupakan penelitian tindakan kelas, yang terdiri dari tiga siklus pembelajaran, dan setiap siklus meliputi empat tahapan yaitu perencanaan, pelaksanaan, evaluasi, dan refleksi. Penelitian dilaksanakan pada 25 siswa kelas XI MAN 3 Lombok Tengah. Instrumen penelitian yang digunakan berupa (1) lembar observasi keterlaksanaan pembelajaran, (2) tes uraian kemampuan berpikir kritis sebanyak 4 (empat) soal, dan (3) lembar penilaian keterampilan metakognisi siswa yang telah dinyatakan valid. Data hasil penelitian dianalisis secara deskriptif. Hasil penelitian menunjukkan bahwa keteralaksanaan pembelajaran untuk setiap siklus dinyatakan baik, sehingga berdampak pada aktivitas metakognisi dan keterampilan berpikir kritis yang berkategori baik. Berdasarkan hasil penelitian dapat disimpulkan bahwa implementasi model pemecahan masalah dengan strategi konflik kognitif dapat meningkatkan keterampilan metakognisi dan keterampilan berpikir kritis siswa kelas XI MAN 3 Lombok Tengah
\end{abstract}

Kata kunci: PBL, Konflik Kongitif, Kemampuan Metakongisi

\section{Improving students' metacognition and critical thinking skills through problem-solving learning models with conflict-cognitive strategies}

\begin{abstract}
Current learning emphasizes students to be able to learn by applying 21st century thinking skills according to the demands of the 2013 curriculum and revised editions such as critical thinking and metacognition. This study aims to improve students' metacognition skills and critical thinking skills in learning physics through the implementation of problem-solving models with cognitive conflict strategies. This research is a classroom action research, which consists of three learning cycles, and each cycle includes four stages, namely planning, implementing, evaluating, and reflecting. The research was conducted on 25 students of class XI MAN 3 Lombok Tengah. The research instrument used in the form of (1) learning implementation observation sheet, (2) 4 (four) test questions on critical thinking skills, and (3) students' metacognition skill assessment sheet that has been declared valid. The research data were analyzed descriptively. The results showed that the implementation of learning for each cycle was declared good, so that it had an impact on metacognition activities and critical thinking skills which were stated to increase each cycle. Based on the results of the study, it can be concluded that the implementation of problem solving models with cognitive conflict strategies can improve metacognition skills and critical thinking skills of class XI students of MAN 3 Lombok Tengah.
\end{abstract}

Keywords: PBL, Conflict-cognitive, Metacognition abilities

How to Cite: Sukaisih, R., Muhali, M., \& Asy'ari, M. (2020). Meningkatkan keterampilan metakognisi dan berpikir kritis siswa melalui pembelajaran model pemecahan masalah dengan strategi konflik-kognitif. Empiricism Journal, 1(1), 37-50. doi:https://doi.org/10.36312/ej.v1i1.329

https://doi.org/10.36312/ej.v1i1.329

\section{PENDAHULUAN}

Proses pembelajaran seyogyanya merupakan suatu proses yang sangat penting untuk diperhatikan oleh para pendidik sebagai sebuah bentuk tugas dalam mentransfer 
pengetahuan dan pengalaman belajar kepada peserta didiknya. Berbagai upaya telah dilakukan untuk memberikan pengalaman belajar dalam menunbuhkembangkan kemampuan berpikir yang implikasinya bermuara pada peningkatan hasil belajar secara optimal yang menjadi tujuan utama pembelajaran. Tuntutan keberhasilan pembelajaran saat ini semakin mengalami perkembangan seiring dengan perkembangan kurikulum pendidikan pada jenjang sekolah menengah seperti yang tercantum dalam Permendikbud nomor 69 tentang kerangka kurikulum SMA/MA (Kemendikbud, 2013). Pembelajaran sesuai kurikulum tahun 2013 dan edisi revisi tahun 2016 menekankan siswa untuk berpikir kritis dan metakognisi.

Berpikir kritis merupakan kemampuan yang menekankan siswa dalam menjelaskan apa yang dipikirkan. Siswa yang belajar untuk berpikir kritis berarti siswa tersebut belajar bagaimana bertanya, kapan bertanya, apa pertanyaannya, bagaimana nalarnya, kapan menggunakan penalaran, dan metode penalaran apa yang dipakai (Ismaimuza, 2010). Seorang siswa dikatakan dapat berpikir kritis apabila mampu menguji pengalamannnya, mengevaluasi pengetahuan, ide-ide, dan mempertimbangkan argumen sebelum mendapatkan justifikasi. Siswa dapat menjadi pemikir kritis apabila dalam pembelajaran guru mengembangkan sikap, keinginan untuk bernalar, ditantang, dan mencari kebenaran (Noordyana, 2016). Kemampuan berpikir kritis dapat dikembangkan melalui serangkaian tahapan atau fase yang harus dibelajarkan kepada siswa selama pembelajaran. Noer (dalam Noordyana, 2016) merangkum pendapat mengenai fase-fase berpikir kritis dari beberapa ahli dan membagi berpikir kritis menjadi empat fase yaitu: (1) fase kepekaan merupakan proses memicu kejadian, memahami suatu isu, masalah, dilema dari berbagai sumber (tanggap terhadap masalah), (2) fase kepedulian merupakan proses merencanakan solusi suatu isu, masalah, dilema dari berbagai sumber, (3) fase produktivitas merupakan proses mengkonstruksi gagasan untuk menyelesaikan masalah, menyimpulkan dan menilai kesimpulan, (4) fase reflektif yaitu proses memeriksa kembali solusi yang telah dikerjakan dan mengembangkan strategi alternatif. Guru dalam mengembangkan kemampuan berpikir kritis hendaknya memfasilitasi dan melakukan tindakan yang mendorong siswa untuk merefleksi kemampuannya. Adapun untuk kepentingan penelitian ini, peneliti membatasi indikator kemampuan berpikir kritis siswa dilihat dari aspek mengidentifikasi, menghubungkan, mengevaluasi dan menganalisis.

Guru dalam pembelajaran khususnya pada mata pelajaran fisika sering kali sebagai pusat pembelajaran dan siswa hanya sebagai objek penerima (Prayogi et al., 2013), sehingga siswa tidak memiliki kesempatan mengembangkan pengetahuan dan kemampuan berpikir kritis. Permasalahan yang umum juga terjadi dalam pembelajaran fisika yaitu pembelajaran terlalu banyak menyajikan pengetahuan jadi dan terlalu banyak membahas fakta dan hukum (Verawati et al., 2013). Kendala atau pembelajaran yang dialami guru dalam pembelajaran fisika yaitu: (1) keterbatasan guru dalam mengelola kegiatan pembelajaran secara maksimal, (2) target waktu untuk pencapaian isi pembelajaran, (3) jumlah siswa yang terlalu banyak, dan (4) kurang variasi dalam memilih model pembelajaran (Bahtiar et al., 2014).

Masalah kualitas pembelajaran selalu menjadi isu yang menarik dibicarakan pada dunia pendidikan, terkait upaya-upaya yang telah dilakukan oleh para peneliti atau praktisi dan pemerintah untuk meningkatkan kualitas pendidikan seperti penyempurnaan kurikulum, melaksanakan penataran-penataran bagi guru, pengadaan sarana-prasarana laboratorium, tetapi kenyataannya usaha tersebut belum juga mendapatkan hasil yang optimal (Sukaisih \& Muhali, 2013). Tantangan guru dalam melaksanakan pembelajaran di abad ke-21 adalah: (1) mengajar dan teknologi; (2) mengajar dengan pandangan baru tentang kemampuan; (3) mengajar dan pilihan; (4) mengajar dan akuntabilitas; (5) mengajar untuk pembelajaran aktif; (6) mengajar untuk konstruksi makna; (7) mengajar dalam masyarakat multikultur (Arends, 2007). Oleh karena itu, penting kiranya dalam proses pembelajaran siswa dilatih untuk berpikir kritis.

Pembelajaran akan berhasil apabila siswa dilatih untuk berpikir dan secara berpikir tentang apa yang dipikirkannya (Muhali, 2017) atau lebih dikenal dengan metakognisi. Metakognisi sangat penting dalam pembelajaran karena harus dilakukan sebelum, selama, dan sesudah pembelajaran (Ya-Hui, 2012) . Guru mengalami kesulitan untuk mengarahkan proses belajar siswa dengan baik selama proses pembelajaran berlangsung dan menuntut 
siswa dalam keterampilan metakognisi membutuhkan waktu yang cukup lama (Muhali, 2017; 2018). Tosun dan Senocak (2013) secara umum keadaan metakognisi siswa tergolong rendah terutama monitoring kognitif, regulasi kognitif, maupun monitoring-regulasi kognitif.

Berbagai upaya telah dilakukan oleh peneliti dalam memperbaiki kualitas pembelajaran di antaranya melalui pendekatan STML untuk meningkatkan aktivitas dan hasil belajar siswa (Sukaisih, 2013), penerapan pendekatan STML dengan strategi siklus belajar empiris-induktif sebagai upaya meningkatkan hasil belajar dan literasi sains teknologi siswa (Sukaisih, 2014), penerapan model problem solving untuk meningkatkan kesadaran metakognitif dan hasil belajar siswa (Sukaisih \& Muhali, 2013), penerapan model guided inquiry dilengkapi penilaian portofolio untuk meningkatkan aktivitas dan hasil belajar fisika siswa (Sukaisih \& Verawati, 2015). Upaya-upaya yang telah dilakukan oleh peneliti secara spesifik belum melatihkan keterampilan berpikir kritis yang terintegrasi dengan keterampilan metakognisi siswa. Hasil observasi peneliti selama melaksanakan kegiatan pembelajaran pada mata pelajaran fisika, indikator kemampuan berpikir kritis siswa dilihat dari aspek mengidentifikasi, menghubungkan, mengevaluasi dan menganalisis belum dapat dilakukan dengan baik oleh sebagian besar siswa. Kelemahan tersebut dapat dilihat pada setiap aspek yaitu: (1) aspek mengidentifikasi, siswa belum mampu secara maksimal mengidentifikasi informasi pengetahuan yang dibutuhkan dan relevan dengan kebutuhan pemecahan masalah, (2) aspek menghubungkan yang dilakukan siswa juga rendah disebabkan kemampuan mengidentifikasi yang rendah, (3) aspek mengevaluasi, siswa sebagian besar belum mampu menilai kinerjanya dalam memecahkan masalah terutama untuk menjustifikasi benar atau tidaknya langkah-langkah dan hasil pemecahan masalah yang telah dilakukan, dan (4) aspek menganalisis, siswa belum mampu melaksanakan analisis pada setiap langkah pemecahan masalah sampai pada perolehan solusi yang benar. Fakta ini mengindikasikan bahwa aktivitas siswa dalam pemecahan masalah belum menunjukkan aspek-aspek kemampuan berpikir kritis dengan baik sehingga kemampuan berpikir kritis sangat penting untuk dilatihkan kepada siswa selama pembelajaran untuk mencapai tujuan sesuai tuntutan kurikulum 2013 dan edisi revisi 2016.

Masalah lain yang ditemukan oleh peneliti pada penelitian sebelumnya tentang penerapan model problem solving untuk meningkatkan kesadaran metakognitif dan hasil belajar siswa (Sukaisih \& Muhali, 2014) adalah rendahnya pemahaman siswa terhadap materi pelajaran misalnya, pada materi pemuaian zat, kalor dan perubahan wujud zat, dan perpindahan kalor. Pembelajaran problem solving yang digunakan untuk meningkatkan kesadaran metakognitif dan hasil belajar agar siswa mampu meregulasi pembelajaran dan sadar dengan apa saja yang telah dipahami dan apa saja yang belum dipahami, sehingga dapat digunakan sebagai rujukan untuk memperbaiki hasil belajar siswa. Pemahaman materi fisika memerlukan pemikiran dan penalaran agar dapat menyelesaikan masalah fisika (Prayogi et al., 2013).

Upaya para peneliti untuk membelajarkan berpikir kritis siswa dalam pembelajaran fisika telah banyak dilakukan. Bahtiar et al. (2014) membelajarkan kemampuan berpikir kritis dengan menggunakan metode diskusi dan guided inquiry, hasil penelitian menunjukkan bahwa siswa yang dibelajarkan dengan diskusi memperoleh pencapaian indikator berpikir kritis pada aspek interpretasi sebanyak $5,71 \%$ siswa, analisis sebanyak 8,57\% siswa, evaluasi sebanyak $14,29 \%$, dan inferensi sebanyak $8,57 \%$, sedangkan pencapaian berpikir kritis yang dibelajarkan dengan model guided inquiry masih perlu diperhatikan pada aspek analisis dan inferensi. Prayogi et al. (2013) telah melatihkan kemampuan berpikir kritis melalui penerapan model POE, hasil penelitian selama 2 (dua) siklus menunjukkan terjadi penurunan kemampuan berpikir kritis dari siklus I ke siklus II pada aspek: (1) meingidentifikasi masalah (53,68\%-47,79\%), (2) mendeskripsikan prediksi penyelesaian masalah (79,4\%-71,3\%), dan (3) menjelaskan hasil observasi (85,3\%-67,6\%), sehingga penting untuk diperhatikan dalam melakukan perbaikan pembelajaran untuk melatihkan ketiga aspek tersebut. Agustiarini (2013) melatihkan kemampuan berpikir kritis siswa melalui pembelajaran dengan model empirical inductive learning cycle, dan hasil yang diperoleh menunjukkan pencapaian berpikir kritis pada 3 (tiga) aspek yang diukur yaitu memberikan penjelasan dasar, berhipotesis dan menyimpulkan, dan membuat penjelasan lebih lanjut, telah mencapai kategori baik, tetapi 
siswa kurang memiliki kepercayaan diri dan kurang termotivasi dalam belajar, sehingga perlu alternatif untuk perbaikan pembelajaran. Afifah \& Putra (2015) telah menerapkan model problem solving untuk melatihkan kemampuan berpikir kritis mahasiswa, dari hasil penelitian ini direkomendasikan untuk menggunakan wacana yang tertuju pada masalah sehingga siswa dapat lebih mudah untuk memahami masalah yang diselesaikan.

Berdasarkan hasil identifikasi permasalahan dalam membelajarkan berpikir kritis seperti diuraikan di atas, maka kemampuan berpikir kritis dalam penelitian ini dibelajarkan menggunakan model problem solving. Komponen langkah-langkah pada model problem solving memungkinkan siswa untuk secara sistematis dapat memecahkan masalah dengan baik dimulai dari memahami masalah, membuat rencana pemecahan masalah, melaksanakan rencana pemecahan masalah, dan melihat kembali sebagai evaluasi atas proses pemecahan masalah yang telah dilakukan, sesuai dengan sintak model yang dikembangkan Polya (1957) yang terdiri dari 4 (empat) fase aktivitas pemecahan masalah yaitu understanding, planning, carrying out the plan, dan looking back. Pembelajaran yang berorientasi pada tahap pemecahan masalah menuntut siswa berpikir untuk memahami dan berpikir tentang informasi yang diperlukan, sampai mendapatkan solusi pemecahan masalah yang benar. Masalah merupakan semua situasi yang menuntut siswa untuk berusaha mencapai tujuan tertentu dan harus menemukan cara untuk menyelesaikannya. Woolfolk (2009) menyatakan bahwa masalah memiliki initial state (keadaan awal), tujuan (hasil yang diinginkan), dan jalan untuk mencapai tujuan itu (termasuk berbagai operasi atau aktivitas yang mengarahkan siswa ke tujuan tersebut).

Penerapan model problem solving pada penelitian ini diintegrasikan dengan strategi konflik kognitif yaitu dengan menciptakan situasi konflik kognitif pada siswa, yang disajikan melalui penyajian fenomena konflik kognitif yang berkaitan erat dengan kehidupan rutin siswa atau fenomena yang tidak rutin bagi siswa (anomali). Thomas (2012) menyatakan bahwa konflik kognitif dapat mempromosikan monitoring pengetahuan dalam proses berpikir dan refleksi pengetahuan awal siswa. Mischel (2007) menyatakan bahwa konflik kognitif merupakan kesadaran atau ketidaksadaran tentang suatu ketidakseimbangan sesaat dalam sistem schemata. Keadaan yang tidak seimbang inilah yang dapat digunakan guru untuk mendorong aktivitas siswa untuk menyelesaikan permasalahan yang diberikan. Konflik kognitif diyakini dapat memberikan kesempatan kepada siswa untuk meregulasi kognitifnya sehingga dapat berpikir akan pengetahuannya dengan baik (Sukaisih \& Muhali, 2013; Muhali, 2018; 2019; Asy'ari et al., 2019).

Penyajian fenomena konflik kognitif dilakukan sebagai kegiatan akhir pada fase kesatu (memahami permasalahan pembelajaran) dan keempat (melihat kembali proses-proses pemecahan masalah) dari model problem solving menurut Polya (1957). Langkah-langkah pembelajaran pada penelitian ini dideskripsikan seperti pada Tabel 1 sebagai berikut.

Tabel 1. Langkah-Langkah Model Pembelajaran dengan Strategi Konflik kognitif

\begin{tabular}{|c|c|c|}
\hline $\begin{array}{l}\text { Sintak/Fase } \\
\text { Problem Solving } \\
\text { (Polya, 1957) }\end{array}$ & $\begin{array}{c}\text { Kegiatan Operasional Problem } \\
\text { Solving (Wankat \& Oreovocz, 1995) }\end{array}$ & $\begin{array}{l}\text { Kegiatan Operasional } \\
\text { Problem Solving dengan } \\
\text { Strategi Konflik Kognitif }\end{array}$ \\
\hline 1. Understanding & $\begin{array}{l}\text { - Membangkitkan motivasi dan } \\
\text { membangun keyakinan diri } \\
\text { siswa. }\end{array}$ & $\begin{array}{l}\text { - Membangkitkan motivasi dan } \\
\text { membangun keyakinan diri } \\
\text { siswa (apersepsi). } \\
\text { - Memfasilitasi siswa dalam } \\
\text { merumuskan masalah. }\end{array}$ \\
\hline & $\begin{array}{l}\text { - Define (mendefinisikan): } \\
\text { membuat daftar hal yang } \\
\text { diketahui dan tidak diketahui. }\end{array}$ & $\begin{array}{l}\text { - Define (mendefinisikan): } \\
\text { memfasilitasi siswa membuat } \\
\text { daftar hal yang diketahui dan } \\
\text { tidak diketahui. }\end{array}$ \\
\hline & $\begin{array}{l}\text { - Explore (mengeksplorasi): } \\
\text { merangsang siswa mengajukan } \\
\text { pertanyaan dan membimbing }\end{array}$ & $\begin{array}{l}\text { - Explore (mengeksplorasi): } \\
\text { merangsang siswa mengajukan } \\
\text { pertanyaan dan membimbing }\end{array}$ \\
\hline
\end{tabular}




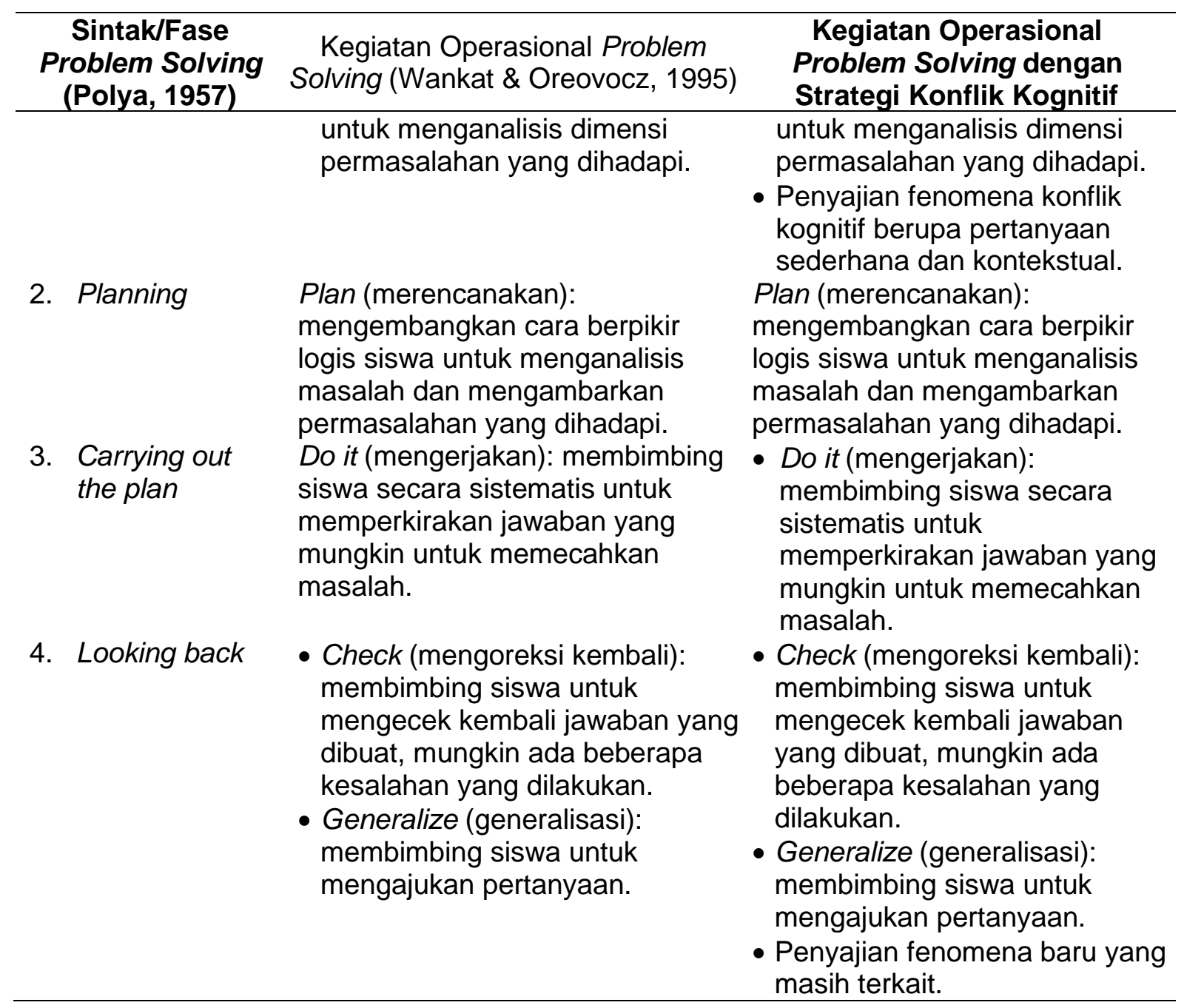

Penerapan model pembelajaran problem solving dikarenakan beberapa keunggulan sebagai berikut: (1) mendidik siswa untuk berpikir secara sistematis, (2) melatih siswa untuk mendesain suatu penemuan, (3) berpikir dan bertindak kreatif, (4) memecahkan masalah yang dihadapi secara realistis, (5) mengidentifikasi dan melakukan penyelidikan, (6) menafsirkan dan mengevaluasi hasil pengamatan, (7) merangsang perkembangan kemajuan berfikir siswa untuk menyelesaikan masalah yang dihadapi dengan tepat, (8) dapat membuat pendidikan sekolah lebih relevan dengan kehidupan,khususnya dunia kerja, (9) mampu mencari berbagai jalan keluar dari suatu kesulitan yang dihadapi, (10) belajar menganalisis suatu masalah dari berbagai aspek, (11) mendidik siswa percaya diri sendiri (Kemendikbud dalam Muhali, 2019).

Berdasarkan uraian di atas, maka rumusan malasah dalam peneitian ini adalah: (1) apakah penerapan model problem solving dengan strategi konflik kognitif dapat meningkatkan keterampilan berpikir kritis dan metakognisi siswa?; (2) bagaimanakah penerapan model problem solving dengan strategi konflik-kognitif dapat meningkatkan keterampilan berpikir kritis dan metakognisi siswa?

Dengan demikian, dari urian dan rumusan masalah yang yang telah dijelaskan maka tujuan penelitian ini adalah meningkatkan keterampilan berpikir kritis dan metakognisi siswa melalui pembelajaran problem solving dengan strategi konflik kognitif pada pembelajaran fisika kelas XI MAN 3 Lombok Tengah tahun pelajaran 2019/2020.

\section{METODE}

Penelitian ini merupakan Penelitian Tindakan Kelas (PTK) yang tujuan utamanya adalah meningkatkan keterampilan berpikir kritis dan metakognisi siswa dalam pembelajaran fisika khususnya dalam pembelajaran materi suhu dan kalor. Penelitian ini dilaksanakan dalam 3 
(tiga) siklus (masing-masing siklus terdiri dari 3 (tiga) pertemuan) dengan 4 (empat) tahap kegiatan, yaitu tahap perencanaan, pelaksanaan tindakan, observasi dan evaluasi, dan refleksi. Tahap perencanaan meliputi: (1) penyusunan silabus dan RPP (rencana pelaksanaan pembelajaran) berbasis problem solving dengan strategi konflik kognitif, (2) menyusun LKS (Lembar Kegiatan Siswa) untuk tiap-tiap pertemuan, (3) membuat instrumen berupa lembar keterlaksanaan pembelajaran, tes keterampilan berpikir kritis, dan lembar penilaian keterampilan metakognisi selama pembelajaran. Tahap pelaksanaan tindakan meliputi: (1) pelaksanaan pembelajaran sesuai dengan RPP, dan (2) pengamatan proses pembelajaran oleh teman sejawat untuk mengamati keterlaksanaan pembelajaran sesuai RPP, para siswa bekerja dalam kelompok, memecahkan masalah sesuai fase yang ditentukan, dan berpedoman pada LKS yang telah disediakan. Tahap observasi dan evaluasi meliputi: (1) kegiatan mengobservasi keterlaksanaan pembelajaran dan keterampilan metakognisi siswa selama pembelajaran yang dilakukan oleh observer, (2) mengevaluasi kemampuan berpikir kritis siswa pada akhir pertemuan di setiap siklus. Tahap refleksi, dengan melakukan peninjauan kembali terhadap keterlaksanaan pembelajaran, keterampilan berpikir kritis, dan keterampilan metakognisi siswa. Secara singkat, rancangan penelitian disajikan pada Gambar 1 di bawah ini.

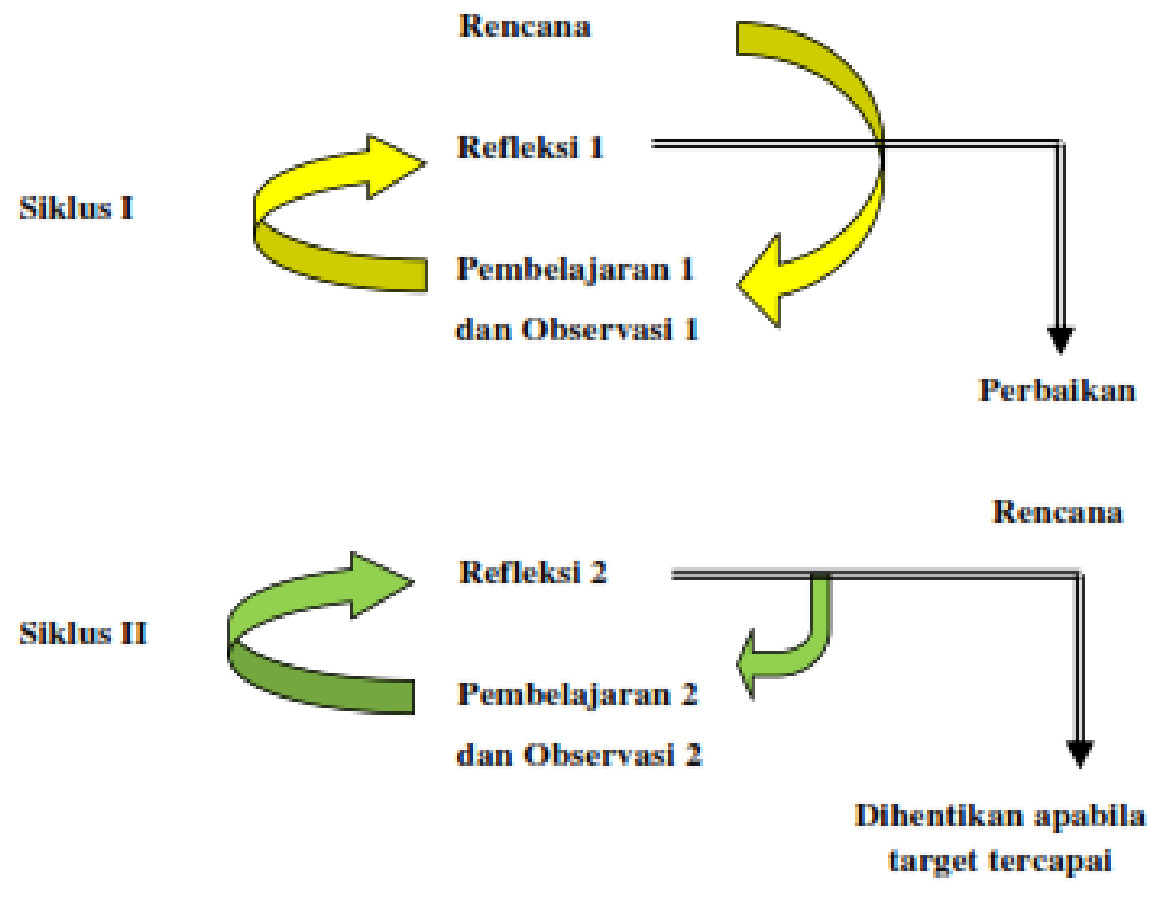

Gambar 1. Alur Penelitian Tindakan Kelas menurut Kemmis \& Mc. Taggart

Subyek penelitian ini adalah siswa kelas XI tahun pelajaran 2019/2020 dengan jumlah siswa 20 orang. Instrumen dalam penelitian ini berupa: (1) lembar observasi keterlaksanaan pembelajaran, (2) tes keterampilan berpikir kritis berupa soal uraian, dan (3) lembar penilaian keterampilan metakognisi siswa. Instrumen lembar observasi keterlaksanaan pembelajaran meliputi serangkaian kegiatan yang tercantum dalam RPP berupa kegiatan guru selama pembelajaran pada setiap pertemuan meliputi kegiatan pada fase understanding, planning, carrying out the plan, dan looking back., sedangkan instrumen tes keterampilan berpikir kritis terdiri dari 4 (empat) soal pada setiap siklus, siklus I (materi persamaan keadaan gas ideal dan hukum Boyle-Gay Lussac), siklus II (materi teori kinetik gas dan tinjauan impuls-tumbukan untuk teori kinetik gas), dan siklus III (materi energi kinetik rata-rata gas, kecepatan efektif gas, dan teori ekipartisi energi dan energi dalam). Instrumen lembar penilaian keterampilan metakognisi yang digunakan pada penelitian ini adalah instrumen yang dikembangkan oleh Muhali $(2018 ; 2019)$ yang meliputi 8 (delapan) aspek di yaitu: (1) perumusan tujuan umum pembelajaran maupun khusus, (2) merumuskan rumusan masalah dan hipotesis, (3) membuat perencanaan pemecahan masalah, (4) melaksanakan perencanaan secara 
sistematis, (5) mengamati proses pelaksanaan perencanaan secara kelompok dan individu, (6) memeriksa proses pelaksanaan perencanaan secara kelompok dan individu, (7) mencatat atau mengumpulkan data, dan (8) mengevaluasi hasil.

Validasi instrumen lembar observasi keterlaksanaan pembelajaran dan keterampilan berpikir kritis siswa dilakukan melalui penilaian 3 (tiga) orang validator dari dosen FSTT Universitas Pendidikan Mandalika. Hasil validasi instrumen ditunjukkan seperti pada Tabel 2 berikut ini.

Tabel 2. Validitas Instrumen Penelitian

\begin{tabular}{|c|c|c|c|c|c|c|c|c|}
\hline \multirow{2}{*}{ No. } & \multirow{2}{*}{ Instrumen yang Dinilai } & \multirow{2}{*}{$\mathbf{N}$} & \multicolumn{6}{|c|}{ Validitas $\left(r_{\alpha}\right)$} \\
\hline & & & Isi & $(\alpha)$ & Konstruk & (a) & Muka & $(\alpha)$ \\
\hline 1 & $\begin{array}{l}\text { Lembar observasi } \\
\text { keterlaksanaan pembelajaran. }\end{array}$ & 24 & 0,933 & 0,965 & 0,938 & $\begin{array}{c}0,96 \\
8\end{array}$ & 0,893 & 0,943 \\
\hline 2 & Lembar observasi & & & & & & & \\
\hline & $\begin{array}{l}\text { keterampilan metakognisi } \\
\text { siswa. }\end{array}$ & 14 & 0,793 & 0,884 & 0,840 & 0,913 & 0,901 & 0,947 \\
\hline 3 & Tes kemampuan berpikir kritis: & & & & & & & \\
\hline & a. Siklus I & 10 & 0,901 & 0,948 & 0,815 & 0,89 & 0,882 & 0,938 \\
\hline & b. Siklus II & 10 & 0,838 & 0,912 & 0,814 & 8 & 0,881 & 0,938 \\
\hline & c. Siklus III & 10 & 0,901 & 0,947 & 0,901 & $\begin{array}{c}0,89 \\
8 \\
0,94 \\
7\end{array}$ & 0,882 & 0,937 \\
\hline
\end{tabular}

Berdasarkan data pada Tabel 2 tersebut dapat dijelaskan bahwa instrumen penelitian berupa lembar observasi keterlaksanaan pembelajaran dan lembar penilaian keterampilan metakognisi siswa selama pembelajaran dinyatakan valid dan reliabel baik secara isi (content validity), konstruk (construct validity), maupun muka (face validity) dan reliabel dilihat dari perolehan nilai a Cronbach alpha, sehingga instrumen-instrumen tersebut dapat digunakan untuk pengumpulan data penelitian melalui pembelajaran model problem solving dengan strategi konflik kognitif. Instrumen tes kemampuan berpikir kritis juga secara isi, konstruk dan muka dinyatakan valid dan reliabel, sehingga dapat digunakan untuk mengukur kemampuan metakognisi pada setiap siklus pembelajaran menggunakan model problem solving dengan strategi konflik kognitif.

Teknik pengumpulan dan analisis data pada penelitian ini adalah sebagai berikut.

1. Data Keterlaksanaan Pembelajaran

Data keterlaksanaan pembelajaran diperoleh dengan teknik observasi yang dilakukan oleh pengamat sebanyak 2 (dua) orang. Pengamat mengisi lembar keterlaksanaan pembelajaran dengan memberikan tanda $(\sqrt{ })$ pada bagian penskoran dari setiap aspek kegiatan yang teramati.

Data keterlaksanaan pembelajaran yang diperoleh berupa skor dengan rentang 1-4, dengan kategori 1 = tidak baik, 2 = kurang baik, 3 = baik, dan 4 = sangat baik. Skor tiap aspek yang didapat dari semua pertemuan yang telah dilaksanakan pada setiap siklus, dihitung skor rata-rata, kemudian diinterpretasikan dalam bentuk skor seperti pada Tabel 3 sebagai berikut. Tabel 3. Interval Skor Rata-rata dan Kriteria Keterlaksanaan Pembelajaran (diadaptasi dari Ratumanan \& Laurens, 2006)

\begin{tabular}{cc}
\hline Interval skor rata-rata & Kriteria skor rata-rata \\
\hline $1,00-1,8$ & Kurang baik (K) \\
$1,9-2,7$ & Cukup baik (C) \\
$2,8-3,6$ & Baik (B) \\
$>3,6$ & Sangat baik (SB) \\
\hline
\end{tabular}

Reliabilitas lembar observasi keterlaksanaan pembelajaran dihitung dengan rumus berikut (Borich, 1994).

$$
\mathrm{R}=1-\frac{A-B}{A+B} \times 100 \%
$$


Keterangan:

$\mathrm{R}=$ Reliabilitas Instrumen

$\mathrm{A}=$ Frekuensi aspek tingkah laku yang teramati oleh pengamat yang memberikan frekuensi tinggi.

$\mathrm{B}=$ Frekuensi aspek tingkah laku yang teramati oleh pengamat yang memberikan frekuensi rendah.

Keterlaksanaan pembelajaran dikatakan reliabel jika nilai reliabilitas yang diperoleh $\geq$ 0,75 , atau sebanyak $75 \%$ dari rerata skor pada setiap deskriptor yang diberikan tim pengamat dengan kategori baik.

2. Keterampilan metakognisi siswa pada setiap pertemuan pembelajaran

Data keterampilan metakognisi siswa diperoleh dari hasil pengamatan selama siswa melaksanakan kegiatan praktikum, dilakukan oleh tim pengamat sebanyak 3 (tiga) orang, dengan memberikan tanda $(\sqrt{ })$ pada bagian penskoran dari setiap indikator yang teramati.

Data keterampilan metakognisi siswa selama pembelajaran pada setiap siklus dianalisis dengan rumus sebagai beikut.

$$
A=\frac{\text { skor yang diperoleh siswa }}{\text { skormaksimal seluruhitem }} x \text { skormaksimal }
$$

Keterangan: $A=$ aktivitas siswa

Skor yang diperoleh siswa selanjutnya dikonversi menjadi 4 (empat) kategori, didasarkan pada Permendikbud No. 81A Tahun 2013 tentang Implementasi Kurikulum seperti pada Tabel 4 di bawah ini.

Tabel 4. Interval Skor Rata-rata Ketermpilan Metakognisi Siswa (Muhali, 2018; 2019)

\begin{tabular}{cc}
\hline Interval skor rata-rata & Kriteria skor rata-rata \\
\hline$A \leq 1,33$ & Kurang baik $(\mathrm{K})$ \\
$1,33<A \leq 2,33$ & Cukup baik $(\mathrm{C})$ \\
$2,33<A \leq 3,33$ & Baik (B) \\
$3,33<A \leq 4,00$ & Sangat baik (SB) \\
\hline
\end{tabular}

3. Keterampilan berpikir kritis

Data keterampilan berpikir kritis diperoleh melalui teknik tes. Tes diberikan kepada siswa setelah menyelesaikan pembelajaran setiap siklus, selanjutnya hasil tes dievaluasi untuk mendapatkan nilai yang diperoleh siswa pada setiap siklus.

Data keterampilan berpikir kritis pada setiap siklus dianalisis dengan menggunakan rumus berikut ini.

$$
K B K=\frac{\text { skor yang diperoleh siswa }}{\text { skormaksimal }} \times 100
$$

Keterangan: $K B K=$ keterampilan berpikir kritis. bawah ini.

Skor yang diperoleh dikategorisasi ke dalam 4 (empat) kriteria seperti pada Tabel 5 di

Tabel 5. Kriteria Keterampilan Berpikir Kritis Siswa

\begin{tabular}{cc}
\hline Predikat & Nilai \\
\hline Sangat Baik (SB) & $80 \leq \mathrm{KBK} \leq 100$ \\
Baik (B) & $70 \leq \mathrm{KBK} \leq 79$ \\
Cukup (C) & $60 \leq \mathrm{KBK} \leq 69$ \\
Kurang (K) & KBK $<60$ \\
\hline
\end{tabular}

Keterampilan berpikir kritis siswa dikatakan berhasil apabila mencapai $85 \%$ siswa mendapatkan nilai dengan kategori baik dan sangat baik, karena syarat siswa dikatakan tuntas jika hasil yang dicapai di atas nilai KKM mata pelajaran fisika MAN 3 Lombok Tengah sebesar 70 . 


\section{HASIL PENELITIAN DAN PEMBAHASAN}

Kegiatan penelitian dilakukan pada 20 orang siswa kelas XI MAN Sengkol Lombok Tengah, dengan menerapkan model pembelajaran pemecahan masalah dengan strategi konflik kognitif untuk meningkatkan kemampuan berpikir kritis dan aktivitas belajar siswa. Pembelajaran dilakukan pada mata pelajaran fisika materi teori kinetik gas, yang dibelajarkan pada semester ganjil tahun pelajaran 2019/2020. Hasil penelitian berupa keterlaksanaan pembelajaran, kemampuan berpikir kritis, dan keterampilan metakognisi siswa selama pembelajaran dideskripsikan sebagai berikut.

Keterlaksanaan Pembelajaran Model Problem Solving dengan Strategi Konflik Kognitif

Data keterlaksanaan pembelajaran memuat semua kegiatan pada fase model problem solving menurut Polya (1957) dan pengintegrasian dengan fenomena konflik kognitif pada fase kesatu dan keempat. Data keterlaksanaan pembelajaran pada 3 (tiga) siklus pembelajaran pada setiap pertemuan disajikan pada Tabel 6 di bawah ini.

Tabel 6. Data Keterlaksanaan Pembelajaran Menggunakan Model Problem Solving dengan Strategi Konflik Kognitif

\begin{tabular}{|c|c|c|c|c|c|c|c|c|c|}
\hline \multirow{2}{*}{ No. } & \multirow{2}{*}{$\begin{array}{c}\text { Fase/Kegiatan yang } \\
\text { Diamati }\end{array}$} & \multicolumn{6}{|c|}{ Siklus/Pertemuan } & \multirow{2}{*}{ Rerata } & \multirow{2}{*}{ Kategori } \\
\hline & & I/1 & $\mathrm{I} / 2$ & $11 / 3$ & $11 / 4$ & III/5 & $I I I / 6$ & & \\
\hline \multirow[t]{9}{*}{1.} & Understanding: & & & & & & & & \\
\hline & $\begin{array}{l}\text { - Apersepsi: } \\
\text { membangkitkan } \\
\text { motivasi dan } \\
\text { membangun keyakinan } \\
\text { diri siswa }\end{array}$ & 3 & 4 & 4 & 4 & 4 & 4 & 3,87 & Sangat baik \\
\hline & $\begin{array}{l}\text { - Memfasilitasi siswa } \\
\text { dalam merumuskan } \\
\text { masalah }\end{array}$ & 3 & 3 & 4 & 4 & 4 & 4 & 3,67 & Sangat baik \\
\hline & $\begin{array}{l}\text { Define } \\
\text { (mendefinisikan): } \\
\text { memfasilitasi siswa } \\
\text { membuat daftar hal } \\
\text { yang diketahui dan } \\
\text { tidak diketahui. }\end{array}$ & 3 & 3 & 3 & 4 & 4 & 4 & 3,65 & Sangat baik \\
\hline & $\begin{array}{l}\text { - Explore } \\
\text { (mengeksplorasi): } \\
\text { merangsang siswa }\end{array}$ & 2 & 2 & 3 & 4 & 3 & 4 & 3,00 & Baik \\
\hline & & & & & & & & & \\
\hline & & & & & & & & & \\
\hline & $\begin{array}{l}\text { permasalahan yang } \\
\text { dihadapi. }\end{array}$ & & & & & & & & \\
\hline & $\begin{array}{l}\text { - Penyajian fenomena } \\
\text { konflik kognitif berupa } \\
\text { pertanyaan sederhana } \\
\text { dan kontekstual. }\end{array}$ & 2 & 2 & 3 & 3 & 4 & 4 & 3,00 & Baik \\
\hline \multirow[t]{2}{*}{2.} & Planning & & & & & & & & \\
\hline & $\begin{array}{l}\text { Plan (merencanakan): } \\
\text { mengembangkan cara } \\
\text { berpikir logis siswa untuk } \\
\text { menganalisis masalah } \\
\text { dan mengambarkan } \\
\text { permasalahan yang } \\
\text { dihadapi. }\end{array}$ & 2 & 3 & 3 & 3 & 4 & 4 & 3,17 & Baik \\
\hline 3. & Carrying out the plan & & & & & & & & \\
\hline
\end{tabular}




\begin{tabular}{|c|c|c|c|c|c|c|c|c|c|}
\hline \multirow{2}{*}{ No. } & \multirow{2}{*}{$\begin{array}{c}\text { Fase/Kegiatan yang } \\
\text { Diamati }\end{array}$} & \multicolumn{6}{|c|}{ Siklus/Pertemuan } & \multirow{2}{*}{ Rerata } & \multirow{2}{*}{ Kategori } \\
\hline & & $\mathrm{I} / \mathbf{1}$ & $1 / 2$ & II/3 & $1 \mathrm{II} / 4$ & III/5 & III/6 & & \\
\hline \multirow[t]{4}{*}{4.} & $\begin{array}{l}\text { Do it: membimbing siswa } \\
\text { secara sistematis untuk } \\
\text { memperkirakan jawaban } \\
\text { yang mungkin untuk } \\
\text { memecahkan masalah. } \\
\text { Looking back: }\end{array}$ & 2 & 2 & 4 & 3 & 3 & 4 & 3,00 & Baik \\
\hline & $\begin{array}{l}\text { - Check (mengoreksi } \\
\text { kembali): membimbing } \\
\text { siswa untuk mengecek } \\
\text { kembali jawaban yang } \\
\text { dibuat, mungkin ada } \\
\text { beberapa kesalahan } \\
\text { yang dilakukan. }\end{array}$ & 3 & 3 & 3 & 4 & 4 & 4 & 3,50 & Baik \\
\hline & $\begin{array}{l}\text { - Generalize } \\
\text { (generalisasi): } \\
\text { membimbing siswa } \\
\text { untuk mengajukan } \\
\text { pertanyaan. }\end{array}$ & 2 & 2 & 3 & 3 & 4 & 4 & 3,00 & Baik \\
\hline & $\begin{array}{l}\text { Penyajian fenomena } \\
\text { baru yang terkait } \\
\text { dengan proses } \\
\text { pemecahan masalah. }\end{array}$ & 2 & 3 & 3 & 3 & 3 & 4 & 3,00 & Baik \\
\hline 5. & $\begin{array}{l}\text { Pengelolaan kelas } \\
\text { selama pembelajaran }\end{array}$ & 2 & 3 & 3 & 3 & 4 & 4 & 3,17 & Baik \\
\hline 6. & $\begin{array}{l}\text { Penggunaan alokasi } \\
\text { waktu }\end{array}$ & 2 & 2 & 3 & 3 & 3 & 4 & 2,83 & Baik \\
\hline
\end{tabular}

Berdasarkan data keterlaksanaan pembelajaran pada Tabel 6 di atas, dari nilai rata-rata ketiga siklus pada semua aspek atau kegiatan pembelajaran sebanyak 8,33\% mencapai kategori sangat baik dan $91,67 \%$ mencapai kategori baik. Data tersebut menunjukkan bahwa secara keseluruhan kegiatan pembelajaran dinyatakan reliabel karena telah melebihi $75 \%$ dari rata-rata skor setiap kegiatan dengan kategori baik (Borich, 1994). Data keterlaksanaan pembelajaran siklus I dan II pada keempat fase problem solving rata-rata mencapai kategori cukup baik, hal ini disebabkan karena: (1) guru belum terbiasa menyajikan fenomena konflik kognitif dalam pembelajaran, sehingga berdampak pada pengelolaan kelas dan penggunaan waktu selama pembelajaran yang mencapai kategori cukup baik; (2) siswa mengalami kesulitan dalam menghubungkan fenomena konflik kognitif yang disajikan guru dengan pengetahuan yang telah dimiliki sebelumnya karena belum terbiasa dengan pembelajaran yang diterapkan oleh guru, yang menyebabkan siswa mengalami kesulitan dalam memonitor dan meregulasi pengetahuannya (Sukaisih \& Muhali, 2013; Tosun \& Senocak, 2013; Muhali, 2018; 2019; Asy'ari et al., 2019).

Keterlaksanaan pembelajaran pada siklus kedua dan ketiga telah mecapai peningkatan dengan rata-rata baik dan sangat baik, hal ini menunjukkan bahwa guru dan siswa telah terbiasa dengan pembelajaran yang diterapkan, terlihat dari pengelolaan kelas dan penggunaan alokasi waktu pembeajaran dengan baik. kenyataan ini menunjukkan bahwa siswa akan terbiasa melakukan kegiatan pembelajaran setelah dilatih secara terus menerus. Sesuai pendapat Woolfolk (2008) bahwa siswa cenderung melakukan tindakan yang menjadi kebiasaannya. Menurut teori belajar perilaku, siswa memiliki kecenderungan untuk melakukan kinerja sesuai dengan apa yang diajarkan (Nur, 2011).

\section{Keterampilan Berpikir Kritis Siswa}

Keterampilan berpikir kritis siswa pada penelitian ini menitikberatkan pada kemampuan siswa dalam mengidentifikasi, menghubungkan, menganalisis, dan 
mengevaluasi, yang diukur dengan menggunakan soal uraian sebanyak 4 (empat) soal pada setiap siklus. Data keterampilan berpikir kritis siswa pada setiap siklus seperti tercantum dalam Tabel 7 berikut ini.

Tabel 7. Nilai Keterampilan Berpikir Kritis Siswa pada Setiap Siklus Pembelajaran

\begin{tabular}{ccccccc}
\hline \multirow{2}{*}{$\mathbf{N}$} & \multicolumn{5}{c}{ Skor rata-rata tiap siklus } \\
\cline { 2 - 7 } & Siklus I & Kriteria & Siklus II & Kriteria & Siklus III & Kriteria \\
\hline 20 & 64,63 & Cukup baik & 69,19 & Cukup baik & 75,61 & Baik \\
\hline
\end{tabular}

Berdasarkan data keterampilan berpikir kritis pada Tabel 7 di atas, pada siklus I sebanyak $40 \%$ siswa memiliki keterampilan berpikir kritis dengan kategori baik, sebanyak $50 \%$ siswa memiliki keterampilan berpikir kritis dengan kategori cukup baik, dan 10\% siswa memiliki keterampilan berpikir kritis dengan kategori kurang baik. Keterampilan berpikir kritis siswa pada siklus II menunjukkan sebanyak 55\% siswa mencapai keterampilan berpikir kritis dengan kategori baik, sebanyak 30\% siswa mencapai keterampilan berpikir kritis dengan kategori cukup baik, sebanyak $15 \%$ siswa mencapai keterampilan berpikir kritis dengan kategori kurang baik. Keterampilan berpikir kritis siswa pada siklus II menunjukkan sebanyak $25 \%$ siswa mencapai keterampilan berpikir kritis dengan kategori sangat baik, sebanyak $60 \%$ siswa mencapai keterampilan berpikir kritis dengan kategori baik, sebanyak $15 \%$ siswa mencapai keterampilan berpikir kritis dengan kategori cukup baik. Secara umum data pada Tabel 7 menunjukkan terjadi peningkatan nilai rerata pada setiap siklus pembelajaran. Peningkatan terjadi dari siklus I dengan rerata 64,63 dengan kategori cukp baik menjadi 75,61 dengan kategori baik pada siklus III. Nilai rerata juga mengalami peningkatan dari siklus I $(64,63)$ ke siklus II $(69,19)$ tetapi peningkatan tersebut masih dalam kategori cukup baik. Berdasarkan data keterampilan berpikir kritis yang dicapai siswa pada siklus III menunjukkan bahwa sebanyak $85 \%$ siswa telah mencapai skor dengan kategori minimal 70 (sesuai KKM) sehingga secara klasikal siswa dikatakan tuntas dalm pembelajaran.

Data keterampilan berpikir kritis siswa setiap indikator dengan menggu nakan model problem solving dengan strategi konflik kognitif pada setiap siklus pembelajaran seperti tercantum pada Tabel 8 di bawah ini.

Tabel 8. Analisis Data Keterampilan Berpikir Kritis pada Setiap Indikator

\begin{tabular}{clcccc}
\hline \multirow{2}{*}{ No. } & \multirow{2}{*}{ Aspek yang Diamati } & \multicolumn{3}{c}{ Rerata Skor Setiap Siklus } & \multirow{2}{*}{ Rerata } \\
\cline { 3 - 4 } & I & II & III & \\
\hline 1. & Mengidentifikasi & 10,12 & 18,40 & 20,35 & 16,29 \\
2. & Menghubungkan & 7,92 & 12,20 & 18,74 & 12,95 \\
3. & Menganalisis & 9,72 & 14,50 & 17,25 & 13,82 \\
4. & Mengevaluasi & 7,20 & 10,99 & 14,48 & 10,89 \\
\hline
\end{tabular}

Berdasarkan data nilai rerata keterampilan berpikir kritis setiap indikator sesuai Tabel 8 mengindikasikan bahwa pencapaian indikator mengidentifikasi lebih baik dibandingkan dengan pencapaian siswa pada indikator menghubungkan, menganalisis, dan mengevaluasi, sedangkan pencapaian siswa pada kemampuan mengevaluasi paling rendah dibandingkan indikator yang lain.

\section{Keterampilan Metakognisi Siswa}

Keterampilan metakognisi siswa yang diukur meliputi: (1) perumusan tujuan umum pembelajaran maupun khusus, (2) merumuskan rumusan masalah dan hipotesis, (3) membuat perencanaan pemecahan masalah, (4) melaksanakan perencanaan secara sistematis, (5) mengamati proses pelaksanaan perencanaan secara kelompok dan individu, (6) memeriksa proses pelaksanaan perencanaan secara kelompok dan individu, (7) mencatat atau mengumpulkan data, dan (8) mengevaluasi hasil. Data keterampilan metakognisi siswa pada setiap siklus pembelajaran dapat dilihat pada Tabel 9 sebagai berikut.

Tabel 9. Keterampilan Metakognisi Siswa Menggunakan Model Problem Solving dengan Strategi Konflik Kognitif

\begin{tabular}{ccccccc}
\hline \multirow{2}{*}{$\mathbf{N}$} & \multicolumn{5}{c}{ Skor rata-rata tiap siklus } \\
\cline { 2 - 6 } & Siklus I & Kriteria & Siklus II & Kriteria & Siklus III & Kriteria \\
\hline 20 & 1,57 & Cukup baik & 2,24 & Cukup baik & 2,61 & Baik \\
\hline
\end{tabular}


Berdasarkan data pada Tabel 9 tersebut enunjukkan bahwa keterampilan metakognisi siswa secara umum pada 8 (delapan) indikator pada siklus I sebanyak $60 \%$ siswa mencapai kategori cukup baik, dan $40 \%$ siswa mencapai kategori kurang baik, pada siklus II sebanyak $50 \%$ siswa mencapai kategori baik, dan $50 \%$ siswa mencapai kategori cukup baik, dan pada siklus III sebanyak 5\% siswa mencapai kategori sangat baik, sebanyak $75 \%$ siswa encapai kategori baik, dan sebanyak $20 \%$ siswa mencapai kategori cukup baik.

Hasil analisis data keterampilan metakognisi siswa pada setiap indikator selama pembelajaran pada setiap siklus dengan menggunakan model problem solving dengan strategi konflik kognitif seperti tercantum pada Tabel 10 sebagai berikut.

Tabel 10. Analisis Data Keterampilan Metakognisi Siswa pada Setiap Aspek yang Diamati

\begin{tabular}{|c|c|c|c|c|c|c|c|}
\hline \multirow{2}{*}{ No. } & \multirow{2}{*}{$\begin{array}{c}\text { Aspek yang } \\
\text { Diamati }\end{array}$} & \multicolumn{6}{|c|}{ Rerata dan Kategori Setiap Siklus } \\
\hline & & I & Kategori & II & Kategori & III & Kategori \\
\hline 1. & $\begin{array}{l}\text { Merumuskan } \\
\text { tujuan } \\
\text { pembelajaran. }\end{array}$ & 1,55 & Cukup baik & 2,39 & Baik & 2,79 & Baik \\
\hline 2. & $\begin{array}{l}\text { Membuat rumusan } \\
\text { masalah. }\end{array}$ & 1,30 & Kurang baik & 2,28 & Cukup baik & 2,76 & Baik \\
\hline 3. & $\begin{array}{l}\text { Membuat } \\
\text { perencanaan } \\
\text { pemecahan } \\
\text { masalah. }\end{array}$ & 1,80 & Cukup baik & 2,33 & Baik & 2,38 & Baik \\
\hline 4. & $\begin{array}{l}\text { Melaksanakan } \\
\text { perencanaan } \\
\text { secara sistematis. }\end{array}$ & 1,65 & Cukup Baik & 2,37 & Baik & 2,64 & Baik \\
\hline 5. & $\begin{array}{l}\text { Mengamati proses } \\
\text { pelaksanaan } \\
\text { perencanaan. }\end{array}$ & 1,30 & Kurang baik & 2,25 & Cukup baik & 2,38 & Baik \\
\hline 6. & $\begin{array}{l}\text { Memeriksa proses } \\
\text { pelaksanaan } \\
\text { perencanaan. }\end{array}$ & 1,10 & Kurang baik & 2,20 & Cukup baik & 2,18 & Cukup Baik \\
\hline 7. & $\begin{array}{l}\text { Mencatat atau } \\
\text { mengumpulkan } \\
\text { data. }\end{array}$ & 2,00 & Cukup baik & 2,30 & Cukup baik & 3,00 & Baik \\
\hline 8. & $\begin{array}{l}\text { Mengevaluasi } \\
\text { hasil. }\end{array}$ & 1,12 & Kurang baik & 1,56 & Cukup baik & 1,58 & Cukup baik \\
\hline
\end{tabular}

Berdasarkan data pada Tabel 10 menunjukkan bahwa dari 8 (delapan) indikator yang diamati, sebanyak 6 (enam) indikator mencapai kategori baik pada siklus III yaitu: (1) perumusan tujuan umum pembelajaran maupun khusus, (2) merumuskan rumusan masalah dan hipotesis, (3) membuat perencanaan pemecahan masalah, (4) melaksanakan perencanaan secara sistematis, (5) memeriksa proses pelaksanaan perencanaan secara kelompok dan individu, (6) mencatat atau mengumpulkan data, sedangkan 2 (dua) indikator mencapai kategori cukup baik yaitu: (1) memeriksa proses pelaksanaan perencanaan, dan (2) mengevaluasi hasil. Secara umum, peningkatan skor pada setiap indikator mengalami peningkatan tetapi peningkatan yang sangat kecil terjadi pada indikator memeriksa proses pelaksanaan perencanaan dan mengevaluasi hasil.

\section{KESIMPULAN}

Berdasarkan hasil penelitian dan pembahasan, maka dapat disimpulkan bahwa penerapan model problem solving dengan strategi konflik kognitif dapat meningkatkan keterampilan metakognisi dan berpikir kritis siswa. Penerapan model problem solving dengan strategi konflik kognitif dapat meningkatkan keterampilan berpikir kritis dan metakognisi siswa dalam 3 (tiga) siklus pembelajaran dengan rerata pelaksanaan semua aspek atau kegiatan pembelajaran sebanyak 8,33\% mencapai kategori sangat baik dan 91,67\% mencapai kategori 
baik. Model pembelajaran problem solving dapat meningkatkan keterampilan berpikir kritis siswa, dilihat dari peningkatan nilai rerata pada setiap siklus pembelajaran yaitu siklus I sebesar 64,63 dengan kategori cukup baik, siklus II sebesar 69,19 dengan kategori cukp baik, dan siklus III sebesar 75,61 dengan kategori baik. Model pembelajaran problem solving dapat meningkatkan keterampilan metakognisi siswa, dilihat dari rerata pada setiap siklus pembelajaran yaitu siklus I sebesar 1,57 dengan kategori cukup baik, siklus II sebesar 2,24 dengan kategori cukup baik, dan siklus III sebesar 2,61 dengan kategori baik.

\section{SARAN}

Berdasarkan hasil penelitian yang telah diuraikan, maka hal-hal yang dapat disarankan pada penelitian ini adalah penerapan model problem solving dengan strategi konflik kognitif dalam pembelajaran perlu mempertimbangkan bentuk fenomena yang disajikan agar lebih sederhana dan merangsang siswa untuk lebih mudah menghubungkan pengetahuan yang telah dicapai dengan langkah-langkah pemecahan masalah. Kesesuaian dan tingkat kedalaman materi pembelajaran harus disajikan secara sistematis dan mempertimbangkan keadaan kognitif siswa terutama pada siswa yang mengalami hambatan atau kesulitan belajar.

\section{UCAPAN TERIMAKASIH}

Penelitian ini tidak menerima hibah khusus dari agensi pendanaan mana pun di sektor publik, komersial, atau nirlaba.

\section{DAFTAR PUSTAKA}

Afifah, N. I., \& Putra, A. P. (2015). Penerapan problem solving terhadap keterampilan berpikir kritis siswa pada subkonsep sistem gerak. Prosiding Seminar Nasional XII Pendidikan Biologi (pp. 254-259). Universitas Negeri Surakarta, Solo-Indonesia.

Agustiarini, S. (2013). Penerapan model pembelajaran empirical inductive learning cycle untuk meningkatkan keterampilan berpikir kritis dan hasil belajar siswa SMAN 1 Gerung tahun ajaran 2011/2012. Prosiding Seminar Nasional Sains dan Inovasi Pembelajaran Berbasis Kearifan Lokal (pp. 52-58). PKPSM IKIP Mataram, MataramIndonesia.

Arends, R. I. (2007). Learning to teach. New York: McGraw Hill Companies, Inc.

Asy'ari, M., Hidayat, S., \& Muhali, M. (2019). Validitas dan efektivitas prototipe buku ajar fisika dasar reflektif-integratif berbasis problem solving untuk meningkatkan pengetahuan metakognisi. Jurnal Inovasi Pendidikan IPA, 5(2), 205-215.

Bahtiar, Nur, M., \& Wasis. (2014). Pengaruh model praktikum sains (IPA) fisika berbasis guided inquiry terhadap keterampilan berpikir kritis siswa kelas X MAN 2 Mataram. Prosiding Seminar Nasional Sains dan Inovasi Pembelajaran Berbasis Kearifan Lokal (pp. 408-416). PKPSM IKIP Mataram, Mataram-Indonesia.

Borich, G. D. (1994). Observation skills for effective teaching. New York: Publishing Company.

Hidayat, S., Asy'ari, M., Muhali, M., \& Sukaisih, R. (2019). The Effect of the Inquiry Learning Model on Students' Metacognition Awareness. Lensa: Jurnal Kependidikan Fisika, 7(2), 31-36.

https://modelpembelajaran1.wordpress.com/2016/02/21/model-pembelajaran-problemsolving/

Ismaimuza, D. (2010). Kemampuan berpikir kritis dan kreatif matematis siswa SMP melalui pembelajaran berbasis masalah dengan strategi konflik kognitif. Disertasi pada SPS UPI Bandung (tidak dipublikasikan).

Mischel, W. (2007). Toward a science of the individual: past, present, future?. In Y. Shoda., Cervone, D., Downey, G. (Eds.), Building a Science of the individual, (pp. 263-277). New York: Guilford.

Muhali, Yuanita, L., Ibrahim, M. (2019). The validity and effectiveness or reflectivemetacognitive learning model to improve students' metacognition ability at SMA in Indonesia. Malaysian Journal of Learning and Instruction, 16(2), 34-73. 
Muhali. (2017). Studi empiris kesadaran metakognisi siswa di SMAN 1 Praya Timur. 458-461. Prosiding Seminar Nasional IKA IKIP Mataram, Epistimologi Perkembangan Kurikulum Pendidikan di Indonesia dan Implementasinya, 25 Maret 2017. Mataram, Indonesia.

Muhali. (2018). Pengembangan model pembelajaran reflektif-metakognitif untuk meningkatkan kemampuan metakognisi siswa SMA. Disertasi pada PPS Universitas Negeri Surabaya. Surabaya.

Noer. (2010). "Peningkatan Kemampuan Berpikir Kritis, Kreatif, Reflektif (K2R) Matematis Siswa SMP Melalui Pembelajaran Berbasis Masalah". Disertasi pada SPs FPMIPA UPI Bandung (tidak dipublikasikan).

Noordyana, M. A. (2016). Meningkatkan kemampuan berpikir kritis matematis siswa melalui pendekatan metacognitive instruction. Jurnal Pendidikan Matematika STKIP Garut, 5(2), 120-127.

Polya, G. (1957). How to solve it. Princeton, NJ: Lawrence Erlbaum.

Prayogi, S., Hidayat, S., \& Wulandari, A. (2013). Penerapan model pembelajaran kooperatif dengan strategi pembelajaran POE (predict observe explain) untuk meningkatkan hasil belajar dan kemampuan berpikir kritis siswa di MAN 1 Mataram tahun pelajaran 2012/2013. Jurnal Lensa Kependidikan Fisika, 1(1), 28-36.

Ratumanan dan Lauren. (2011). Evaluasi Hasil Belajar pada Tingkat satuan Pendidikan Edisi 2. Surabaya. Unesa University Press.

Sukaisih, R. \& Muhali. (2014). Meningkatkan kesadaran metakognitif dan hasil belajar siswa melalui penerapan pembelajaran problem solving. Jurnal Pengkajian IImu dan Pembelajaran Matematika dan IPA "Prisma Sains", 2(1), 244-255.

Sukaisih, R. \& Verawati, N. N. S. P. (2015). Penerapan model guided inquiry dilengkapi penilaian portofolio untuk meningkatkan aktivitas dan hasil belajar fisika siswa. Prosiding Seminar Nasional Pembelajaran dan Penilaian Sains Sesuai Tuntutan Kurikulum 2013 (pp. 268-271). Pendidikan Sains Universitas Negeri Surabaya, Surabaya-Indonesia.

Sukaisih, R. (2013). Penerapan pendekatan sains teknologi masyarakat dan lingkungan (STML) sebagai upaya meningkatkan aktivitas dan hasil belajar siswa pada pembelajaran rangkaian listrik dan hukum Ohm. Jurnal Kependidikan Fisika "Lensa", 1(2), 132-135.

Sukaisih, R. (2014). Penerapan pendekatan sains teknologi masyarakat dan lingkungan (STML) dengan strategi siklus belajar empiris-Induktif sebagai upaya meningkatkan hasil belajar dan literasi sains teknologi siswa. Prosiding Seminar Nasional Sains dan Inovasi Pembelajaran Berbasis Kearifan Lokal (pp. 550-555 ). PKPSM IKIP Mataram, Mataram-Indonesia.

Thomas, G. P. (2012). Metacognition in science education: Past, present and future considerations. In G.J. Fraser, K. G. Tobin, C. J. McRobbie (Eds.) Second international handbook of science educations, (pp. 131-144). New York: Springer.

Verawati, N. N. S. P., Wahyudi, \& Sahidu, C. (2014). Mengembangkan keterampilan berpikir kritis mahasiswa dengan penerapan model pembelajaran inkuiri. Prosiding Seminar Nasional Sains dan Inovasi Pembelajaran Berbasis Kearifan Lokal (pp. 556-561). PKPSM IKIP Mataram, Mataram-Indonesia.

Wankat, P.C., \& Oreovocz, F.S. (1995). Teaching enginerring. New York: McGraw Hill, Inc.

Woolfolk, A. 2009. Educational Psychology Bagian Kedua Edisi Kesepuluh. Yogyakarta: Pustaka Pelajar.

Ya-Hui, W. (2012). A study on metacognition of college teachers. The Journal of Human Resource and Adult Learning, 8(1), 84-91. National Taitung University. Taiwan. 